\title{
Viburnum opulus: Could it be a new alternative, such as lemon juice, to pharmacological therapy in hypocitraturic stone patients?
}

\author{
Devrim Tuglu ${ }^{1}$, Erdal Yılmaz ${ }^{1}$, Ercan Yuvanc ${ }^{1}$, Imge Erguder ${ }^{2}$, Ucler Kisa ${ }^{3}$, \\ Fatih Bal ${ }^{1}$, Ertan Batislam ${ }^{1}$ \\ ${ }^{1}$ University of Kirikkale, Faculty of Medicine, Department of Urology and ${ }^{3}$ Biochemistry, ${ }^{2}$ University of Ankara Faculty \\ of Medicine, Department of Biochemistry, Turkey.
}

\begin{abstract}
Summary Objective: Citrate, potassium, and calcium levels in Viburnum opulus (V. opulus) and lemon juice were compared to evaluate the usability of $\mathrm{V}$. opulus in mild to moderate level hypocitraturic stone disease.

Materials and Methods: V. opulus and lemon fruits were squeezed in a blender and 10 samples of each of $100 \mathrm{ml}$ were prepared. Citrate, calcium, sodium, potassium, magnesium, and $\mathrm{pH}$ levels in these samples were examined. Results: Potassium was found to be statistically significant$l y$ higher in V. opulus than that in lemon juice $(p=0.006)$ whereas sodium $(p=0.004)$ and calcium $(p=0.008)$ were found to be lower. There was no difference between them in terms of the amount of magnesium and citrate.

Concusions: Because V. opulus contains citrate as high as lemon juice does and it is a potassium-rich and calciumand sodium-poor fluid, it can be an alternative to pharmaceutical treatment in mild-to-moderate degree hypocitraturic stone patients. These findings should be supported with clinical studies.
\end{abstract}

KEY WORDS: Viburnum opulus; Hypocitraturic; Urinary stone; Lemon juice.

Submitted 24 October 2014; Accepted 31 October 2014

\section{INTRODUCTION}

Urinary tract stone disease affects $12 \%$ of the world's population and its recurrence can be as high as 50\% at 10 year follow up (1). With the widespread use of SWL and introduction of endoscopic techniques, studies on medical stone treatment have been reduced and pushed to the background (2).

Urinary tract stones are formed through a marked increase in the saturaton of a solute substance in the urine. One of the changeable factors affecting solubility is $\mathrm{pH}$. Increase in the value of urinary $\mathrm{pH}$ raise the point of solubility and may prevent stone formation (3). The agents commonly used to treat hypocitraturia and alkalinizing urine are sodium citrate and potassium citrate $(4,5)$. Many studies have shown that citrate replacement reduces rates of stone recurrence. However, patient compliance to pharmacotherapy with potassium citrate can be difficult. Due to gastrointestinal side effects and the high number of tablets to take throughout the day, 3-year treatment dropout rates of patients are as high as 25 percent $(2,5)$. Natural citric acid intake can be used as an alternative to pharmacotherapy in patients who are incompatible, or who cannot tolerate potassium citrate. There are studies that have used lemonade, orange, grapefruit, lime, or tomato to aim this target (6-11). These studies emphasize that they can be a good alternative to pharmacotherapy in mild to moderate hypocitraturia. Oxidative stress and renal tubular cell injury are observed in urinary tract stone patients. Lipid peroxidation begins in the cell membrane as a consequence of the toxicity of free radicals. When cell membrane integrity breaks down, cell balance begins to disappear, and cell death starts. Antioxidants may be used in order to avoid this situation (12). Viburnum opulus (V. opulus) has antioxidant properties (13-15) and we think that it may have a place in the medical treatment of stone disease. Not only with its antioxidant properties, but also with its content of potassium and citrate, it suggests being beneficial in the prevention of stone disease. In our study, $V$. opulus is compared in terms of citrate, calcium, phosphorus, magnesium, sodium, potassium and $\mathrm{pH}$ to lemon, which is known as a source of natural citrate, and the usability of V. opulus in hypocitraturic stone disease patients is discussed.

\section{Material AND MEthod}

Because V. opulus has a bitter taste when first collected, the fruit was kept in brine water for a month to make it lose its bitterness. After having made it drinkable, it was squeezed in a blender and 10 samples of each of $100 \mathrm{ml}$ were collected. Ten samples of $100 \mathrm{ml}$ each were taken from lemons in the same manner. During evaluation, no dilutions were made with water or any other solution and no sugar was added to prevent the direct effect of a liquid or sugar to the variables to evaluate.

The resulting extract was centrifuged for $15 \mathrm{~min}$ at $2000 \mathrm{~g}$. Citrate, oxalate, calcium, phosphorus, magnesium, sodi- 
um, potassium, chloride, and $\mathrm{pH}$ levels were examined in all samples.

Samples were grouped as follows: Group 1. V. opulus juice held in brine; Group 2. Fresh lemon juice

An enzyme-spectrophotometric method was used to determine citrate in biological fluids It is based on citrate lyase and phenylhydrazine reactions. The enzyme converts citrate into oxaloacetate, which, in the presence of phenylhydrazine, is transformed into the corresponding phenylhydrazone. The ultraviolet-absorbing product is determined by absorbance measurement at $330 \mathrm{~nm}$ (16). The method is based on the following reactions:

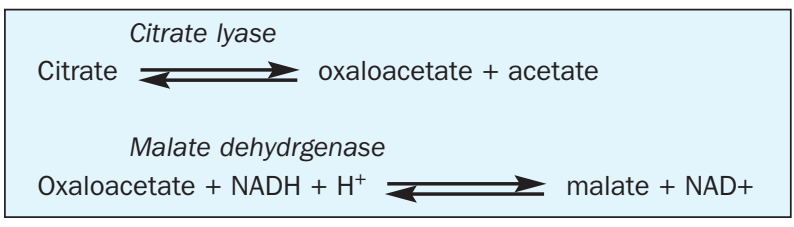

Calcium, phosphorus and magnesium (Roche Diagnostics $\mathrm{GmbH}$, Mannheim) were colorimetrically measured by a Hitachi P800 autoanalyser (Hitachi High-Technologies Co., Japan). Sodium and potassium were analyzed in the Hitachi P800 autoanalyser using ion-selecting electrodes. A pH meter Precisa pH 900 device was used to verify pH. Wilcoxon Rank-Sum test was used in the statistical evaluations for comparison of the parameters.

\section{Results}

The citrate and magnesium contents of $V$. opulus have been found not statistically different from than of lemon juice. Potassium has been found statistically higher than in lemon juice (p: 0.006) whereas sodium (p: 0.004) and calcium (p: 0.008) were lower. Table 1 shows the citrate, calcium, sodium, potassium, phosphorus, magnesium and $\mathrm{pH}$ values in lemon juice and $\mathrm{V}$. opulus contents.

\section{Table 1.}

Concentration of solutes and $\mathrm{pH}$ value in the two fluids.

\begin{tabular}{|l|c|c|}
\hline & V. opulus & Lemon juice \\
\hline Citrate $(\mathrm{mmol} / \mathrm{L})$ & $65.22 \pm 5.86$ & $54.04 \pm 5.05$ \\
\hline Potassium $(\mathrm{mmol} / \mathrm{L})$ & $40.51 \pm 2.78$ & $27.55 \pm 2.12$ \\
\hline Calcium $(\mathrm{mmol} / \mathrm{L})$ & $0.05 \pm 0.01$ & $1.52 \pm 0.02$ \\
\hline Magnesium $(\mathrm{mmol} / \mathrm{L})$ & $1.57 \pm 0.26$ & $1.44 \pm 0.21$ \\
\hline Sodium $(\mathrm{mmol} / \mathrm{L})$ & $2.54 \pm 0.19$ & $6.35 \pm 0.98$ \\
\hline pH & $4.02 \pm 0.16$ & $4.03 \pm 0.18$ \\
\hline
\end{tabular}

\section{Discussion}

A well known inhibitor of calcium-based stones is citrate. Citrate reduces calcium oxalate and phosphate saturation by forming calcium-soluble complexes and by inhibiting crystal nucleation and growh (4). With an incidence of 16-63\%, hypocitraturia is an important etiological factor in recurrent calcium nephrolithiasis (3). It has been demonstrated that pharmacological potassium citrate intake increases urine citrate levels and reduces urine calcium excretion as well as relative saturation of calcium oxalate in hypocitraturia (2). Alternatives to potassium citrate have been sought in recent years due to patient non-compliance, particularly due to gastrointestinal poor tolerance (17-45\%), and to the severe financial burden (a daily dose price of $\$ 3.90$ in Turkey) (5). Significant increases in urinary volume, $\mathrm{pH}$, potassium, magnesium and citrate excretion have been obtained in patients with hypocitraturic stone disease by the addition of fruit and vegetable juices to the diet $(7,17,18)$. In addition, this has also been reported to provide dilution of lithogenic risk factors in the urine without affecting the concentration of potassium and citrate (19). In particular, various studies have established that the use of citrate extracts and juices as a natural source of citrate can be an alternative to potassium citrate $(6,8)$. It has been shown that high concentrations of citrate in citrus products may affect urine citrate excretion $(20,21)$. Orange juice causes an alkali load by increasing net gastrointestinal alkali absorption, increases urinary $\mathrm{pH}$ and citrate and reduces ammonium and net acid excretion. It is also reported that daily consumption of one liter of orange juice increases citraturia and $\mathrm{pH}$ and prevents stone formation and reduces crystallization risk factors for calcium phosphate $(8,22,23)$.

Although grapefruit juice has been shown to have higher citrate content, it has not been possible to demonstrate that it reduces urinary risk factors $(24,25)$. In addition, grapefruit juice may affect metabolism of commonly used drugs by inhibiting the cytochrome P-450 (24).

The citraturic effect of lemonade have been established by a variety of studies. An advantage of lemonade to orange juice is that its citric acid content is high and calcium content is low $(9,20,26)$.

$\mathrm{V}$. opulus is known to be widely used in Turkey, especially in stone disease. This plant is a species within the Caprifoliaceae (Honeysuckles) family within the Dipsacales order. The plant's trunk, bark and fruits are utilized in pharmacology and as food in the form of pickles, jams, and in various other ways (27). In Central Anatolia, Turkey, especially in the city of Kayseri, it is widely termed as Gilaburu. There are no studies in literature about the mechanism of action of $V$. opulus in stone disease. We believe that it may be active by two ways: 1. Antioxidant properties 2. Possible citrate and potassium content of the plant.

Several studies have been carried in recent years establishing that $V$. opulus has a high potential of antioxidant activity and antimicrobial characteristics depending on the composition of the substances it contains (13-15, 28). It has also been shown to have beneficial effects in the gastrointestinal mucosa thanks to its antioxidant properties (29).

Comparison of citrate and potassium content of V. opulus, which has also antioxidant properties, to citrate and potassium content in lemon juice was the purpose of this study. We demonstrated that if V. opulus is citrate- and potassium-rich, therefore in relation to both its antioxidant properties and its high content in citrate and potassium, it could be argued that it can be an alternative to pharmacological agents in the treatment of hypocitraturic stone patients. In our study it has been found that potassium content in $V$. opulus content is higher than that of lemon juice whereas calcium content is lower. No statistically sig- 
nificant difference from lemon juice in terms of the content of citrate was observed. This result suggests us that $V$. opulus may have a citraturic effect as much as lemon juice and can also provide an alkali load due to its high content of potassium. This alkali load increases urinary citrate excretion by reducing renal tubular reabsorption and citrate metabolism. In addition to alkalinizing urine, alkali load also affects citrate reabsorption from the kidneys. The low calcium and sodium content of $V$. opulus could also be considered as an advantage for stone patients.

\section{Conclusions}

In our study, we have identified citrate and potassium $V$. opulus content as high as that in lemon juice. Due to its antioxidant properties as well as to its high content of both citrate and potassium, $V$. opulus can be recommended to stone patients. We think that it is advisable just as lemon or orange juice in mild-to-moderate hypocitraturia as an alternative to potassium citrate. However, clinical trials on this subject are desirable.

\section{References}

1. Menon M, Parulkar BG, Drach GW. Urinary lithiasis: etiology, diagnosis and medical management. In: Walsh PC, Retik AB, Vaughan ED Jr, Wein AJ, editors. Campbell's Urology. 7th ed. Philadelphia, PA: W.B. Saunders Co.1998, pp 2659-2752.

2. Pak CY. Medical management of urinary stone disease. Nephron Clin Pract. 2004; 98:c49-c53.

3. Pak CY. Kidney stones. Lancet. 1998; 351:1797-1801.

4. Pak CY. Citrate and renal calculi: an update. Miner Electrolyte Metab. 1994; 20:371-377.

5. Barcelo P, Wuhl O, Servitge E, et al. Randomized double-blind study of potassium citrate in idiopathic hypocitraturic calcium nephrolithiasis. J Urol. 1993; 150:1761-1764.

6. Koff SG, Paquette EL, Cullen J, et al. Comparison between lemonade and potassium citrate and impact on urine $\mathrm{pH}$ and 24-hour urine parameters in patients with kidney stone formation. Urology. 2007; 69:1013-1016.

7. Meschi T, Maggiore U, Fiaccadori E, et al. The effect of fruits and vegetables on urinary stone risk factors. Kidney Int. 2004; 66:2402-2410

8. Odvina CV. Comparative value of orange juice versus lemonade in reducing stone-forming risk. Clin J Am Soc Nephrol. 2006; 1:1269-1274.

9. Seltzer MA, Low RK, McDonald M, et al. Dietary manipulation with lemonade to treat hypocitraturic calcium nephrolithisis. J Urol. 1996; 156:907-909.

10. Tosukhowong P, Yachantha C, Sasivongsbhakdi T, et al. Citraturic, alkalinizing and antioxidative effects of limeade-based regimen in nephrolithiasis patients. Urol Res 2008; 36:149-155.

11. Yilmaz E, Batislam E, Basar M, et al. Citrate levels in fresh tomato juice: a possible dietary alternative to traditional citrate supplementation in stone-forming patients. Urology. 2008; 71:379-383.

12. Selvam R. Calcium oxalate stone disease: role of lipid peroxidation and antioxidants. Urol Res. 2002; 30:35-47.

13. Rop O, Reznicek V, Valsikova M, et al. Antioxidant Properties of European Cranberrybush Fruit (Viburnum opulus var. edule) Molecules. 2010; 15:4467-4477.
14. Altun ML, Citoglu GS, Yllmaz BS, Coban T. Antioxidant properties of Viburnum opulus and Viburnum lantana growing in Turkey. Int J Food Sci Nutr. 2007; 5:1-6.

15. Andreeva TI, Komarova EN, Yusubov MS, Korotkova EI. Antioxidant activity of cranberry tree (Viburnum opulus L.) bark extract. Pharma Chem J. 2004; 38:548-550.

16. Petrarulo M, Facchini P, Cerelli E, et al. Citrate in urine determined with new citrate lyase method. Clin Chem. 1995; 41:15181521.

17. Parivar F, Low RK, Stoller ML. The influence of diet on urinary stone disease. J Urol. 1996; 155:432-440.

18. Siener $R$, Hesse A. The effect of different diets on urine composition and the risk of calcium oxalate crystallisation in healthy subjects. Eur Urol. 2002; 42:289-296.

19. Borghi L, Meschi T, Maggiore U, Prati B. Dietary therapy in idiopathic nephrolithiasis. Nutr Rev. 2006; 64:301-312.

20. Aras B, Kalfazade N, Tugcu V, et al. Can lemon juice be an alternative to potassium citrate in the treatment of urinary calcium stones in patients with hypocitraturia? A prospective randomized study. Urol Res. 2008; 36:313-317.

21. Gettman MT, Ogan K, Brinkley LJ, et al. Effect of cranberry juice consumption on urinary stone risk factors. J Urol. 2005; 174:590-594.

22. Campoy Martínez P, Arrabal Martín M, Blasco Hernández P, et al. Orange juice in the prevention of calcium oxalate lithiasis. Acta Urol Esp. 1994; 18:738-743.

23. Wabner CL, Pak CY. Effect of orange juice consumption on urinary stone risk factors. J Urol. 1993; 149:1405-1408.

24. Goldfarb DS, Asplin JR. Effect of grapefruit juice on urinary lithogenicty. J Urol. 2001; 166:263-267.

25. Hönow R, Laube N, Schneider A, et al. Influence of grapefruit-, orange- and apple-juice consumption on urinary variables and risk of crystallization. Br J Nutr. 2003; 90:295-300.

26. Kang DE, Sur RL, Haleblian GE, et al. Lemonade-based dietary manipulation in patients with hypocitraturic nephrolithiasis. J Urol. 2007; 177:1358-1362.

27. Soylak M, Elci L, Saracoglu S, Divrikli U. Chemical analysis of fruit juice of European cranberry bush (Viburnum opulus) from Kayseri, Turkey. Asian J Chem. 2002; 14:135-138.

28. Cesonienè L, Daubaras R, Viškelis P, Sarkinas A. Determination of the total phenolic and anthocyanin contents and antimicrobial activity of Viburnum opulus fruit juice. Plant Foods Hum Nutr. 2012; 67:256-61

29. Zayachkivska OS, Gzhegotsky MR, Terletska OI, et al. Influence of Viburnum opulus proanthocyanidins on stress-induced gastrointestinal mucosal damage. J Physiol Pharmacol. 2012; 57 Suppl 5:155-67.

\section{Correspondence}

Devrim Tuglu, MD (Corresponding Author)

devrimtuglu@gmail.com

Erdal Yilmaz, MD

Ercan Yuvanc, $M D$

Fatih Bal, MD

Ertan Batislam, MD

University of Kirikkale, Faculty of Medicine, Department of Urology

Saglik Sokak, 71100, Kirikkale, Turkey

Imge Erguder, MD

University of Ankara Faculty of Medicine, Department of Biochemistry Ankara, Turkey

Ucler Kisa, MD

University of Kirikkale, Faculty of Medicine, Department of Biochemistry Kirikkale, Turkey 